https://doi.org/10.52240/1857-2367.2020.2(21).46

\title{
PARTICULARITĂŢILE MORFOBIOLOGICE ALE UNOR SPECII DIN GENUL HEMEROCALLIS L.
}

\author{
Svetlana MANOLE, Alexandra BULGARU \\ Grădina Botanică Națională (Institut) „Al. Ciubotaru”, \\ Chișinău, Republica Moldova
}

\begin{abstract}
In the National Botanical Garden (Institute) "Al. Ciubotaru", four species from the family Xanthorrhoeaceae, subfamily Hemerocallidoideae were studied: Hemerocallis citrina Baroni, H. lilioasphodelus L., H. minor Mill, H. Middendofii Trautv.\&C.A. Mey. The characteristics of growth, development and ontogenesis were established.

Key word: Hemerocallis L., species, morphology, flowering, fruiting, phenology.

Conservarea diversităţii speciilor de plante de interes ornamental din flora spontană autohtonă și a speciilor alohtone este deosebit de importantă atât din punct de vedere științifică, cât și practică. În acest sens, testarea plantelor spontane din alte zone geografice în condițiile Republicii Moldova și studiul caracteristicilor lor biomorfologice sunt necesare pentru a înțelege capacităţile lor de adaptare. Genul Hemerocallis L. a fost mai mult timp atribuit familiei Liliaceae, apoi familiei Hemerocallidaceae, fapt specificat în mai multe surse bibliografice (Takhtajan A. 1987; Cerepanov S., 1995). Din anul 2009 a fost acceptată, în baza cercetărilor moleculare, familia Xanthorrhoeaceae (The plant list. 2020), care este împărţită în trei subfamilii: Asphodeloideae Burnett, Xanthorrhoeoideae M. W. Chase, Reveal \& M. F. Fay și Hemerocallidoideae Lindley. Reprezentanții ultimei subfamilii au o răspândire geografică largă, preponderent în regiunile tropicale și temperate. Speciile de hemerocalis sunt cultivate în scopuri ornamentale și alimentare,

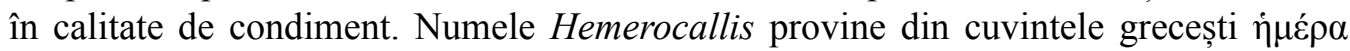

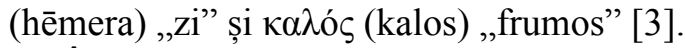

În colecția Grădinii Botanice Naționale (Institut) ” A. Cuibotaru” sunt menținute speciile: H. citrina Baroni - crin galben-lămâie, H. lilio-asphodelus L. - crin galben, H. minor Mill. - crin mic, H. middendorffii Trautv.\&C.A. Mey - crin Midendorffi. Acestea sunt plante
\end{abstract}


policarpice cu rizom scurt. Studiul ritmului de creștere și dezvoltare al acestora a arătat că, în condițiile zonei Centrale a Republicii Moldova, regenerarea, înflorirea și fructificarea sunt observate din aprilie până în august-septembrie (Tabelul 1). Conform clasificării, acestea

Tabelul 1. Fazele fenologice ale speciilor de Hemerocallis.

\begin{tabular}{|c|l|c|c|c|c|c|}
\hline $\begin{array}{c}\mathrm{Nr} . \\
\mathrm{crt}\end{array}$ & \multicolumn{1}{|c|}{ Specia } & Originea & $\begin{array}{c}\text { În c e p u } \mathrm{u} u \\
\text { vegetatiei }\end{array}$ & Îmbobocirea & $\begin{array}{c}\text { Înițierea } \\
\text { infloririi }\end{array}$ & Fructificarea \\
\hline 1. & H. minor Mill. & Siberia de Vest & $07.04-04.05$ & $10.05-30.05$ & $28.05-01.06$ & $28.07-10.08$ \\
\hline 2. & H. lilioasphodelus $\mathrm{L}$. & Siberia de Ves & $07.04-04.05$ & $22.05-04.06$ & $14.06-25.06$ & $18.07-02.08$ \\
\hline 3. & $\begin{array}{l}\text { H. middendorffi } \\
\text { Trautv.\&C.A. Mey }\end{array}$ & $\begin{array}{c}\text { E x t r e m u } \\
\text { Orient }\end{array}$ & $07.04-21.04$ & $15.04-20.04$ & $10.05-03.06$ & $26.06-10.07$ \\
\hline 4. & H. citrina Baroni & China & $15.04-20.04$ & $05.05-20.05$ & $22.05-13.06$ & $28.07-02.09$ \\
\hline
\end{tabular}

sunt plante perene cu înflorire timpurie, cu creștere îndelungată. Semințele de culoare neagră, rotunde sau triunghiulare, lucioase. Germinarea semințelor hipogee [1,2].

Colecția generică Hemerocallis actualmente cuprinde cca 60 taxoni, fiind menținută în GBNI mai bine de trei decenii. Speciile se caracterizează prin începutul timpuriu al vegetației. Creșterea începe în prima decadă a lunii aprilie, prima sau a doua decadă a lunii mai. Dezvoltarea suprafeței frunzelor este foarte rapidă. Începutul înmuguririi poate fi din a doua decadă a lunii aprilie sau prima decadă a lunii mai. Înflorirea speciilor, în dependență de condițiile climaterice ale anului, are loc de la începutul lunii mai, durând 20-35 de zile. Clonele plantelor pe parcursul a 5-7 ani de vegetație formează 15-22 lăstari generativi. Fructificarea speciilor începe cu a treia decadă a lunii iunie.

H. citrina se caracterizează prin înflorire secundară de toamnă (prima decadă a lunii septembrie), dar nu abundentă. Lăstarii generativi se formează anual.

Speciile introduse au model mixt de înflorire care durează 24-28 de ore. Florile sunt așezate și înfloresc în direcția acropetală. Inflorescența este un dihaziu simplu sau cu mai multe niveluri, cu axe laterale puternic inegale. Plantele sunt rezistente la temperaturile scăzute din zona noastră și agenții patogeni.

Polimorfismul ridicat al speciei indică o mare capacitate de variabilitate intraspecifică, hibridizare și obținerea de forme hibride promițătoare pentru amenajarea spațiilor verzi în localitățile urbane și rurale.

Cercetările au fost realizate în cadrul proiectului 20.80009.7007.14 „Cercetări privind mobilizarea diversităţii vegetale cu potenţial ornamental pentru conservarea ex-situ”.

\section{BIBLIOGRAFIE SELECTIVĂ}

1. Manole S. Improvement of Daylilees (Hemerocallis L.) in the Republic of Moldova, Materiale Congres Științific Internațional: Științele vieții, o provocare pentru viitor, Lucrări științifice UASMV Ion Ionescu de la Brad, IAȘI, România, Seria Horticultură, vol. 61/2018, p.325-331.

2. Sava V. Țurcanu V. Particularitățile biomorfologice ale unor specii și soiuri din genul Hemerocallis introduse în Republica Moldova. Mediul ambiant Nr.2 (74) aprilie, 2014, p.98-100.

3. Полетико O.M. Hemerocallis L. - Красоднев, или Лилейник // Декоративные травянистые растения. - Л.: Наука, 1977. -Т. 2.-С . 99-105. 